\title{
THE ROLE OF PRINCIPALS IN THE EFFECTIVE UTILIZATION OF INSTRUCTIONAL MATERIALS AMONG SELECTED SECONDARY SCHOOLS IN KADUNA STATE NIGERIA
}

\author{
Michael Olugbenga \\ National open university of Nigeria \\ M.ED Educational Administration and Planning \\ DOI: $10.31364 /$ SCIRJ/v7.i9.2019.P0919700 \\ http://dx.doi.org/10.31364/SCIRJ/v7.i9.2019.P0919700
}

\begin{abstract}
This study investigated the role of principals in the effective utilization of instructional materials. It also examined the relationship between schools where principal perform supervisory roles in ensuring effective utilizations of instructional materials and schools where principals lack supervision on the use of instructional materials. The survey method was used to gather information. The simple sampling was used to select subjects. The research subjects were 100 educational officers drawn from 10 public secondary schools, randomly selected from 10 local government areas of Kaduna State. Two instruments were designed by the researcher and used for this study. The reliability of the instruments was done using the split- half method; this is a method of estimating the reliability of test scores by the means of single form of a test. Data were analyzed using simple percentage. The analysis revealed that the principals busy schedule, lack of fund, lack of maintenance culture, lack of storage facilities were some of the factors that interfered with the role of principals in ensuring effective utilization of instructional materials. From the 2 hypotheses tested, the result showed that there was significant difference between principals who perform supervisory roles and the ones that don't. It also revealed from the three research questions that principals who delegate authority, encourage teachers on improvisation, frequent in classroom visitation allows for effective utilization of instructional materials than principal that don't. Therefore, it is imperative that all principals need to regularly monitor the activities of teachers, regularly organize staff development programmes and principals should delegate authority due to busy schedule. Recommendation and classroom implication were subsequently drawn for effective utilization of instructional materials.
\end{abstract}

Keywords: effective utilization, instructional materials, school governing bodies

\section{Background to the Study}

The role of a school principal in Nigeria has undergone significant changes for the reasons among many is the instruction of school governing bodies to help checkmate the activities of the principals. Over the past two decades the Nigerian government has made concerted effort to improve the quality of education in the country. Although considerable progress has been made in decentralizing responsibility and authority within the educational system, improving educational quality remains a challenge. A matter of growing concern is that most schools in Nigeria are not functioning adequately and someone has to be held accountable for the apparent low level of performance in schools. The education trust fund act (1993) indicates that the principal is accountable for the academic performance of their school. Thus, in order to improve these results more effective leadership is needed from principals. Principals are key role players in the developing and maintaining of academic standards in schools. John (2007) stated that the poor academic standards could be amongst other reasons, indicative of a lack of effective leadership and commitment as school level. A number of researchers concur with the belief that many school principals lack the skills to effectively manage and lead their schools. The rapid 
rate at which change has taken place and still is taking place together with the increased volume of paper work, has placed the principal under an enormous amount of pressure. Goslin (2009) argues that many principals overlook their responsibilities of instructional leadership because they are not fully aware of their primary task or because they are too busy attending to administrative duties of managing the building and its people.

Utilization of instructional material is the act of using and applying the available instructional material in the actual teaching and learning process. Where resources are supplied for instructional use, teachers are expected to utilize them to support a smooth and meaningful flow of instruction and promote understanding of content being taught.

Principals as school heads therefore, need to provide this support to teachers, they have to be involved in the implementation of instructional programmes by overseeing what teachers are doing with the students. A good principal devote himself to supervise the teaching learning process in his school. As a result, the principal as the supervisor provides professional guidance to teachers in order to improve the conditions which affect learning and growth of the students and teachers. In discharging his supervisory roles, the principals can help the teachers for better task performance in the following areas: preparation of lesson plans and lesson notes before going for lessons; good use of instructional methods and effective use of instructional materials, keeping and maintaining of school record etc.

The research questions are:

(1) What roles do principals' play in the effective utilization of instructional materials among secondary schools?

(2) What constraints do principals' face as hindrance to effective supervision of utilization of instructional materials?

(3) How does supervision by principals enhance utilization of materials in instruction?

\section{Statement of the Problem}

The problem to be researched is the role of principals in the effective utilization of instructional materials in secondary schools. The research problem can be encapsulated with the following questions:

- Do principals perform their roles as school head?

- What do school principals perceive as their core duties?

- How do principals influence the utilization of instructional materials in schools?

- What challenges do principals face in balancing their dual roles of manager and instructional leader? 


\section{Research Questions}

The research questions are:

(4) What roles do principals' play in the effective utilization of instructional materials among secondary schools?

(5) What constraints do principals' face as hindrance to effective supervision of utilization of instructional materials?

(6) How does supervision by principals enhance utilization of materials in instruction?

\section{Research Hypotheses}

The hypotheses generated are: Will there be any significant difference in schools where principals perform supervisory roles in ensuring effective utilizations of instructional materials and schools where principals lack supervision on the use of instructional materials.

Will there be any significance difference in the schools where female or male principals perform supervisory roles in ensuring effective utilization of instructional materials in schools in Kaduna state.

Will there be any significance difference in terms of qualification and principal's role in ensuring effective utilization of instructional materials.

\section{Purpose of the Study}

In view of the problem formulated above, the general aim of this research is to determine the role of principals in the effective utilization of instructional materials in secondary schools. In order to realize the aim of this study, the following objectives are set namely to:

- $\quad$ Understand the role of principals in schools

- $\quad$ Explore principals understanding of their core duties

- Understand how principals can influence the use of instructional materials in schools

- $\quad$ Identify the challenges principals face in balancing their dual roles of manager and instructional leadership.

\section{CONCEPT OF INSTRUCTIONAL MATERIALS}

Oluyori (2006) Stated that instructional materials are of visual, audio and audio -visual that helps to make concept abstract and ideas concrete in the teaching and learning process. They are also materials which the teacher uses in supplementing his teachings. www.scirj.org 
Instructional materials include materials used to facilitate learning for better results. Likewise, it is the use of the chalkboard, charts, models, overhead projectors, films, television and computers in teaching process. Hence, it is not just the use of tools of technology alone but a systematic, integrated organization of machines hardware and software and man, teachers to the problems of education. The component of instructional materials available to teachers and students are in large numbers and also vary according to the functions of each of them. Pictures (motion and still) graphics, maps, radio - recording and play back and the equipments used to get some these utilized can be regarded as instructional materials. Examples of instructional materials are charts, maps, diagrams, comics, models, globes, slides, film strips, television, radio cassettes, video, recorders, cinema, and public address systems, laboratories, and museums, flash cards, flannel boards, card boards, calendar, computers, etc

\section{Effects of Instructional Materials on Secondary School Students}

Instructional materials are essential and significant tools needed for teaching and learning of school subjects to promote teachers efficiency and improve students' performance. They make learning more interesting, practical, realistic and appealing. They also enable both teacher and students to participate actively and effectively in lesson sessions. They give room for acquisition of skills and knowledge and development of self- confidence and self -actualization. Ibeneme (2000) defined instructional materials as those materials used for practical and demonstration in the class situation by students and teachers. Ikerionwu (2000) saw instructional materials as objects as devices that assist the teacher to present a lesson to the learners in a logical manner.

In his own perspective, Fadeiye (2005) saw instructional materials as visual and audio- visual aids, concrete or non- concrete, used by the teachers to improve the quality of teaching and learning activities in schools. Agina - obu (2005) submitted that instructional materials of all kinds appeal to the sense organs during teaching and learning. Isola (2010) also described instructional materials as objects or devices that assist the teacher to present their lessons logically and sequentially to the learners. Abdu (2014) acknowledged that instructional materials are such used by teachers to aid explanations and make learning of subject matter understandable to students during teaching learning process.

In the same vein, Obanya (2004) asserted that several studies carried out in some areas in Nigeria indicated that the results of senior school certificate Examination was completely bad in nearly all subjects offered by the students. He stressed further that only about $10 \%$ of candidates "meaningfully passed" the examination. Abdu (2011) asserted that non availability and inadequacy of instructional materials are major causes of ineffectiveness of the school system and poor performance of students in schools. Ahmed (2003) confirmed that in most secondary schools in Nigeria, teaching and learning take place under a most un- condusive environment without access to essential materials. Eniayewu (2005) posited that it is very important to use instructional materials for instructional 
delivery to make students acquire more knowledge and to promote academic standard. In addition, Ajayi (2001) stressed the importance of availability of instructional materials to achieving effectiveness in educational delivery and supervision in the school system. Ogbodah (2003) alerted on the gross inadequacy and underutilization of instructional materials necessary to compensate for the inadequacies of sense organs and to reinforce the capacity of dominant organs. He noted that school teachers should try their possible best in the provision of locally made materials in substitution for the standard ones to promote their lessons. Enaigbe (2009) noted that basic materials such as textbooks, chalkboard and essential equipment like computer, projector, television, and video are not readily available in many schools. Jekayinfa (2010) observed that instructional materials help teachers to teach conveniently and the learners to learn easily without any problem. They asserted that instructional materials have direct contact with all sense organs. Kocharr (2012) supported that instructional materials are very significant teaching and learning tools. He suggested the needs for teachers to find necessary materials for instruction to supplement what textbooks provide in order to broaden concepts and arouse students' interest in the subject. According to Abolade (2009) the advantages of instructional materials are that they are cheaper to produce useful in teaching large number of students at a time, encourage learners to pay proper attention and enhance their interest.

\section{The Role of Principals in Promoting Utilization of Instructional Materials}

Principals are now more than ever focused on students' achievement while still retaining their traditional administrative and building manager duties because of this, principals typically work ten hours in a day and many believe the job is just not "doable" as it is configured now (Usdan and Podmostko, 2007).

It is estimated that principals are second only to teachers in their impact on student achievement. A highly effective principal can increase his or her students' scores up to percentile points on standardized tests in just one year. Principals can also affect other students' outcomes including reducing student absence and suspension and improving graduation rates. Principals in low achieving or high poverty, minority schools tend to have a greater impact on student outcomes than principals at less challenging schools. Although the gains in student achievement temporarily slow whenever there is a new principal, the impact is felt more at the most challenging schools (Michael, 2009).

The role of the principal has changed dramatically over the past couples of decades. It wasn't too long ago that a principal's primary tasks were limited to making sure the buses ran on time, ordering supplies and addressing personnel issues. Nowadays a principal main responsibility is students learning. Since the administrative and building management duties have not disappeared. 
Today, principals must spend much more time in classrooms than in the office and they focus on curriculum and instruction as well as collecting and analyzing and using data to improve students' achievement. On top of that, they are expected to rally students, teachers and the community to help achieve these goals (Usdan 2007). Among numerous duties of a principal includes

- $\quad$ Principles of effective instruction

- $\quad$ Curriculum design, implementation, evaluation and refinement

- $\quad$ Principles related to implementing a strategic plan

- Information sources, data collection and analysis

- $\quad$ How to inspire others with the vision that all children can learn at high levels.

Several researchers show that principals play a significant role in student achievement. One study found that an average school led by a highly effective principal formed 10 percentage points higher than if that school was led by an average principals(Nully, 2003). A more recent study found that based on value added scores, having a highly effective principal increased students achievement from the $50^{\text {th }}$ percentile to between the $54^{\text {th }}$ and the $58^{\text {th }}$ percentile in just one year, depending on the type of analysis conducted. Effective principals typically do the following

- Set goals and provide a vision: The foundation for being an effective principal is establishing a school - wide vision and commitment to high standard and success of all students. This is essential in creating a culture of academic success for all students within a school. Doing so means the principals spells out high expectations and rigorous learning goals all students are expected to meet. Not only is setting goals important but instilling the belief in teachers that they can reach these goals too. Principals who are able to inspire their teachers in this way have a small but positive impact on student achievement.

- $\quad$ Principals are instructional leaders: principals that provide teachers with instructional leadership improve a student achievement. A principal's instructional leadership has about three to four times more impact on student achievement than transformational leadership where principals focus on motivation and improving the morale of their teachers (Robinson, 2008). Principals show instructional leadership by setting a culture within the school that supports continual professional learning and by taking explicit steps to support individual teachers. Some studies have shown that principals provide instructional support by encouraging teachers collaboration, ensuring the use of instructional materials in schools and emphasize the value of research based strategies and applying them effectively to their own school. A school principal should be positive, enthusiastic, have their hand in the day to day activities of the school and listen to what their constituents are saying. Effective principals are available to teachers, staff members, parents, students and community members. 
- $\quad$ Principals shapes the vision of academic success for all students: researchers who have examined education leadership agree that effective principals are responsible for establishing a school wide vision of commitment to high standards and the success of all students. The principal creates a climate hospitable to education. Effective principals ensure that the schools allow both adults and children to put learning at the centre of their daily activities. The principal ensure safety and orderliness, as well as less tangible qualities such as a supportive, responsive attitude toward the children and a sense by teachers that they are part of a community of professionals focused on good instructions. The principals job also engage parents and the community, many principals work to engage parents and others outside immediate school.

- General administrative duties include the professional management of a school; time tabling; admission and placement of learners; financial management and accountability; keeping a school journal; management and maintenance of the physical structure and equipment; management of hostels, if one is attached to the school; disseminating and storing departmental circulars and other relevant information to staff members timeously, and handling correspondence received at school.

\section{Theoretical Framework}

\section{Theories of leadership}

As the concept of leadership has been studied by various researchers from different perspective, different theories have emerged. The three key theories of leadership are the trait, Behavioural and contingency theories. Trait theories place emphasis on personal characteristics. They assume that "leaders are born; some people are born with characteristics and skills of leadership". The inherent characteristics include outstanding personality, intelligence, social and communication skills. According to Keith (2009) trait theories suggest that a single leadership style is superior in all kinds of organization. The Behavioural theories focus on interaction between the expectations and perceptions of followers in an organization. They look at what leaders actually do when dealing with subordinates and how subordinates react emotionally and behaviourally.

The researcher sees the contingency theory as the most appropriate to the educational situation. Contingency theories define good leadership as the ability to match the right leadership style with the situation. The situation includes the nature of task, the environment and the characteristics of subordinates. Schools differ from situation to situation and educators differ in their maturity and levels of motivation. There is no good or bad leadership but all depends on the situation. One leader may be good in one situation but poor in another situation.

The principals need to adjust their leadership behaviours to suit the educator's willingness, abilities and confidence as well as demands of the situation; for example highly motivated and highly maturity level educators require a delegating style of leadership 
while new teachers require a directive style of behaviour. According to Gargling (2009) different situations call for different styles of leadership in order promote action like the use of instructional materials and the teacher becomes satisfied. In support of this view point Lovell (2004) suggests that the educational organization needs professional behaviour that is characterized by creativeness, originality, adaptability, willingness and competence to take on the risk of leadership.

\section{Current Trends in Leadership (Principal)}

The leadership theories determine the leadership approaches. Two approaches can be distinguished, the transactional and transformational leadership. The former, according to Caldwell (2002), entails getting things done by analytical and logical means. The leader classifies the roles and task requirement of subordinate in order to motivate them in the direction of established goals like the effective utilization of instructional materials. Impersonal aspects of performance such as plans, schedules and budget are stressed. The emphasis is placed on commitment to the organization and conformity to its norms and value. Transformational leadership builds on transactional leadership unlike the transactional leaders; it serves to inspire the followers. The leader and followers lift each other to higher levels of motivation and morality. The leaders pay attention to the concern and developmental needs of teachers. They excite, arouse and inspire followers to put in extra effort to achieve organizational goals. The leaders motivate their followers by appealing to high levels of personal motivation, such as self - actualization, by offering followers to learn new skills and to participate in projects that lead to important outcomes. Boove (2003) see this approach as essential in organizational development because followers are motivated to do more than expected to achieve superior performance.

Transactional leadership has been practiced for several years in most traditional schools. The principals determine the goals of the schools and formulate all plans, schedules and procedures to achieve the goals. Educators could not be involved in decision making activities. They were compelled to conform to the values and standards set by principals. Supervision was a vital aspect of principals' role in effective utilization of instructional materials. Such an approach does not contribute to the professional development of educators.

\section{Principal and learners}

Louis (2004) made two important claims first "leadership is second only to classroom instruction among all school related factors that contribute to what students learn at school". Second, "leadership effects are usually largest where and when they are needed most". Without a powerful leader, troubled schools are unlikely to turn around. In addition emotional intelligence displayed, for example, through a leader's personal attention to an employee and through the utilization of the employee capacities, increases the employee's 
enthusiasm and optimism, reduces frustration, transmits a sense of mission and indirectly increases performance. Anderson (2004) agreed to the assertion that leadership practices help develop people:

- $\quad$ Stimulate them intellectually

- $\quad$ Provide them with individualized support

- $\quad$ Provide them with appropriate model.

Principals strengthen school culture when they clearly and consistently articulate high expectation for all students. Principals can modify organizational structures, for instance, by changing schedule to ensure that teachers share common planning time and use that time to discuss improving instruction. This kind of restructuring also reinforces the use of collaborative process among teachers.

\section{METHODOLOGY}

The aim of this study would be to develop a comprehensive description of the role of principals in the effective utilization of instructional materials in schools in Kaduna state. The survey research will be utilized in this study. Besides that, this chapter would cover several aspects which are research design, the population and sampling, the instrumentation of the measurement, data collection, data analysis and the pilot study that has been carried out.

\section{Research Design}

To gain a better insight into the participants' the role of principals is effective use of instructional materials. This study adopted survey method. According to connote 2009, survey method is the technique of gathering data by asking question to people who are thought to have desired information.

The instrument that would be utilized to collect data is the structured questionnaire titled the role of principals in the effective utilization of instructional materials. This study will use survey method to collect and analyze data to determine the relationship between independent valuable and dependent valuables and further establish the role of principals in effective utilization of instructional materials.

The methods involved in survey data collection are any number of ways in which data can be collected for statistical survey. These are methods that are used to collect information from a sample of individuals in a systematic ways (Daniel, 2002).

The questionnaire sought information on the role of school. Principals how principals influence the utilization of instructional materials in schools, the challenges faced by the principals in ensuring effective utilization of instructional materials and also the effective of instructional materials on academic performance of students in Kaduna State. 
Interview was also conducted in order to reflect emotions and experiences. The implies that interview were conducted with the express aim of finding out what participants think, feel and what they have to say about the roles of principals in the effective utilization of instructional materials.

\subsection{Population of the Study}

According to Dickson (2009) the population is the 'group' a researcher sets out to study while Bailey (2008) defines the population as the sum total of all the units of analysis. He further stated population is any group of individuals that has one or more characteristics in common that are of interest to the researcher. The population of this research would consist of 100 teachers from 10 different public schools. The target population were teachers which would be picked from each school both male and female teachers, although the researcher would have liked to obtain data from teachers and some principals in all schools in Kaduna.

\section{Public schools that may be sampled}

\begin{tabular}{|c|c|c|c|c|}
\hline Areas & Schools & $\begin{array}{c}\text { female } \\
\text { Teachers }\end{array}$ & Male teachers & Total \\
\hline Barnawa & Government day Barnawa & 5 & 5 & 10 \\
\hline Zaria & Government day Basawa & 5 & 5 & 10 \\
\hline Gonin Gora & Government day. & 5 & 5 & 10 \\
\hline Sabon tasha & Government day yelwa. & 5 & 5 & 10 \\
\hline Tudun wada & Government day school & 3 & 7 & 10 \\
\hline Riga chukun & Government day school & 4 & 6 & 10 \\
\hline Kujama & government day school & 5 & 5 & 10 \\
\hline Kakuri & Government day kakuri & 5 & 5 & 10 \\
\hline Ungwan romi & government day Romi & 7 & 3 & 10 \\
\hline Zaria & government secondary school & 5 & 5 & 10 \\
\hline
\end{tabular}


The research population will cover $55 \%$ of the actual size of the recommended population of some selected schools in Kaduna state.

WwW.scirj.org 


\section{Sample and Sampling Technique}

A sample can be described as a subset of the population. The sample must therefore have properties which make it representative of the whole, this means a limited number of element selected from a population to be representative of that population. According to Slavin (2009) the most important principle in sampling is that each member of the population from which sample is drawn should have an equal and known probability of being selected. He further stated that sampling implies taking a portion of the population, making observation on smaller group and then generalizing findings to the larger population. The main purpose of drawing a sample from a population is to obtain information concerning that population. It is important that individuals included in a sample constitute a representative cross section of individuals in the populations. There are various types of sampling which include simple random, stratified random, cluster and systematic sampling. For this study the simple random sampling was used. The sample is a limited number of elements selected from a population to be representative of that population. The sampling of the secondary schools as well as the participants for my study was informed by the purposive preference in-qualitative research. As advocated by Mariam (2009) purposeful sampling is based on the assumption that the investigator wants to discover, understand and gain insight and therefore must select a sample from which the most can be learned. The sampling technique used in this study was called purposive sampling. It was used to select a sample of 10 educational officers from 10 different public schools from Kaduna State. I chose the participants purposively because each of them was able to give me information on the role of principals in the effective use of instructional materials in schools because of the positions they held within the educations system.

\section{Simple Random Sampling}

Simple random sampling was done when selecting the schools from Kaduna State. Walden (2007) support simple random sampling in that all individuals have equal and independent chance of being selected. He further stated that he sees random sampling as suitable and not being subjected to the biases of the researcher. In selecting schools according to simple random sampling the researcher obtained a list of schools for Kaduna state from the ministry of education. There are over 50 public secondary schools. Only 10 schools had to be selected. The researcher had to select 10 secondary schools from the first 20 local governments on the list.

\section{Instrumentation}

For the study, the survey - questionnaire instruments were used to achieve the main objective of the study. A self-Administered questionnaire was distributed to the selected teachers in the schools. The questionnaire given to the teachers aimed to access the role of principals in the effective utilization of instructional materials in schools, it also aims to evaluate effect of instructional materials on the students' academic performance. 
The questionnaire was structured in such a way that the respondents will be able to answer it easily. Thus, the set of questionnaire was structured using the Likert format with a four - point response scale. A Likert scale is a rating scale that requires the subject to indicate his or her degree of agreement and disagreement to a statement. In this kind of questionnaire, the respondents were given five response choices. These options served as the quantification of the participants' agreement and disagreement on each question item.

\section{Validity and Reliability of the Instrument}

This study the role of principals in the effective use of instructional materials is undertaken to measure only the effective use of instructional materials. The questionnaire for survey has been systematically constructed with two questionnaires given to the teachers. The teachers were randomly picked, 10 teachers from each school and are all at the rank of education officers in their various schools.

One of the questionnaires will serve as a "gold standard" which has already been validated, while the other would be completed by the teachers. This is to ensure that the result of the research is nearest to the truth as much as possible.

\section{Administration and Collection of Questionnaires}

Prepared and typed questions were given out to 100 secondary school teachers in Kaduna state. The respondents were engaged in their various schools mostly on Fridays. The distributions of questionnaires were administered by the researcher and would personally collect them. All questionnaires were retrieved as the researcher met the teachers' one on one. The data has been recorded and updated simultaneously as responses are received. The results have been organized in a spread sheet that has been developed to measure the attitudes from the data of the survey results.

\section{Method of Data Analysis}

The analysis of the survey is processed using descriptive statistical tool such as frequency, simple percentage and mean. 


\section{DATA ANALYSIS AND RESULT}

\section{Field Performance of the Research Instrument}

This chapter presents the findings, analysis and interpretation of data gathered whose main objective is to found out the role of principals in the effective utilization of instruction materials.

More specifically, the researcher sought to answer the following questions.

Sub-problem No. 1: what roles do principals play in the effective utilization of instructional materials among secondary schools?

Sub-problem No 2: what constraints do principals face as hindrance to effective supervision of utilization of instructional materials.

Sub-problem No 3: how does supervision by principals enhance utilization of materials in instruction.

Analysis of the Performance of the Questionnaire

\begin{tabular}{lllll}
\hline \hline Administered & Retrieved & Lost & Validated & Invalidated \\
\hline $100 \%(\mathrm{~N}=100)$ & 100 & $0 \%$ & $0 \%(\mathrm{~N}=0)$ & $0 \%(\mathrm{~N}=0)$ \\
& $(\mathrm{N}=100)$ & & $(\mathrm{N}=0)$ & \\
\end{tabular}

www.scirj.org

(C) 2019, Scientific Research Journal

http://dx.doi.org/10.31364/SCIRJ/v7.i8.2019.P0819700 


\section{Demographic characteristics of respondents}

\section{GENDER}

Male

Female

Total

\section{AGE BRACKET}

$35-40$

$41-45$

$46-50$

51 and above

Total

\section{MARITAL STATUS}

Single

Married

Divorced

Separated

\section{FREOUENCY}

$46 \%(\mathrm{n}=23)$

$54 \%(\mathrm{n}=27)$

$100 \%(\mathrm{~N}=50)$

$26 \%(\mathrm{n}=13)$

$26 \%(\mathrm{n}=13)$

$36 \%(\mathrm{n}=18)$

$100 \%(\mathrm{~N}=50)$

$0 \%(\mathrm{n}=0)$

$96 \%(\mathrm{n}=48)$

$4 \%(\mathrm{n}=2)$

$0 \%(\mathrm{n}=0)$

\section{Total}

$100 \%(\mathrm{~N}=50)$

Table 4.2 represents the bio-data of respondents. The Male gender is 23 which indicate (46\%) while the female gender is 27 which indicate $(54 \%)$.

Respondents 6 (12\%) falls between the ages of 35-40,13 (26\%) are between the age of 41-45 ages, $13(26 \%)$ are between the age of 46-50 years while 18 (36\%)are between the age of 51 and above years.

Respondents $0(0 \%)$ are singles, $48(96 \%)$ are married, $2(4 \%)$ are divorced and respondent $0(0 \%)$ is separated.

\section{Role of Principals in Effective Utilization of Instructional Materials}

\begin{tabular}{lllllll}
\hline \hline ITEMS & & SA & A & U & P & Total \\
\hline Principals & support teachers' & $92 \%(\mathrm{n}=46)$ & $8 \%(\mathrm{n}=4)$ & $0 \%(\mathrm{n}=0)$ & $0 \%(\mathrm{n}=0)$ & $100 \%(\mathrm{~N}=50)$
\end{tabular}

instructional method and their

modifications of instructional 
approaches and materials

Principals allocate resources $54 \%(n=27)$

$38 \%(\mathrm{n}=19)$

$0 \%(\mathrm{n}=0)$

$8 \%(n=4)$

$100 \%(\mathrm{~N}=50)$

and materials

Principals frequently visits $56 \%(\mathrm{n}=8)$

$40 \%(n=20)$

$0 \%(\mathrm{n}=0)$

$4 \%(n=2)$

$100 \%(\mathrm{~N}=50)$

classroom for instructional

purpose.

Principals solicit and provide $66 \%(n=33)$

$28 \%(n=14)$

$2 \%(n=1)$

$4 \%(n=2)$

$100 \%(\mathrm{~N}=50)$

feedback on instructional

methods and techniques.

Regularly check lesson plans. $\quad 58 \%(\mathrm{n}=29)$

$$
38 \%(\mathrm{n}=19)
$$

$4 \%(\mathrm{n}=2)$

$0 \%(\mathrm{n}=0)$

$100 \%(\mathrm{~N}=50)$

Principals encourage teachers $74 \%(n=37) \quad 24 \%(n=12)$

$0 \%(n=0)$

$100 \%(\mathrm{~N}=50)$

to improvise instructional

materials.

The principals discusses

feedback with teachers after $50 \%(n=25)$

$42 \%(n=21)$

$0 \%(\mathrm{n}=0)$

$8 \%(\mathrm{n}=4)$

$100 \%(\mathrm{~N}=50)$

classroom supervision

The principals always follow $74 \%(n=37)$

$22 \%(n=11)$

$0 \%(n=0)$

$4 \%(n=2)$

$100 \%(\mathrm{~N}=50)$

up teachers'.

Evaluation and selection of $38 \%(n=19)$

$38 \%(\mathrm{n}=19)$

$0 \%(\mathrm{n}=0)$

$24 \%(n=12)$

$100 \%(\mathrm{~N}=50)$

1. $92 \%$ of respondents strongly agree that principals support teacher's instructional method and their modification of instructional approaches and materials, $8 \%$ also agrees, while $0 \%$ disagrees.

II. $54 \%$ of respondents strongly agree that principals allocate instructional materials, $38 \%$ also agree that principals allocate resources while $8 \%$ disagree.

III.56\% of the respondents strongly agrees that principals frequently visit the classroom for instructional purpose. $40 \%$ agree while $4 \%$ disagrees.

IIII. $66 \%$ of the respondents strongly agree that principals solicit and provide feedback on instructional methods and technique, $28 \%$ agree, $1 \%$ undecided while $4 \%$ disagrees.

V.58\% of the respondents strongly agrees that principals check lesson plans, $38 \%$ agrees, $4 \%$ undecided while $0 \%$ disagrees.

VI.74\% of the respondents strongly agreed that principals encourage teachers to improvise instructional materials, $24 \%$ agreed, $0 \%$ undecided while $2 \%$ disagreed. 
VII. $50 \%$ of the respondents strongly agree that principals discusses feedback with teachers after classroom visitation, $42 \%$ agrees, $0 \%$ undecided while $8 \%$ disagrees.

VIII. 74\% of the respondents strongly agree that principal's follows up teachers work after the performance review meeting, $22 \%$ agrees, $0 \%$ undecided while $4 \%$ disagrees.

VIIII. $38 \%$ of the respondents strongly agree that principals evaluate and select instructional materials, $38 \%$ agrees, $0 \%$ undecided while $24 \%$ disagree.

\section{Constraints Faced by Principals}

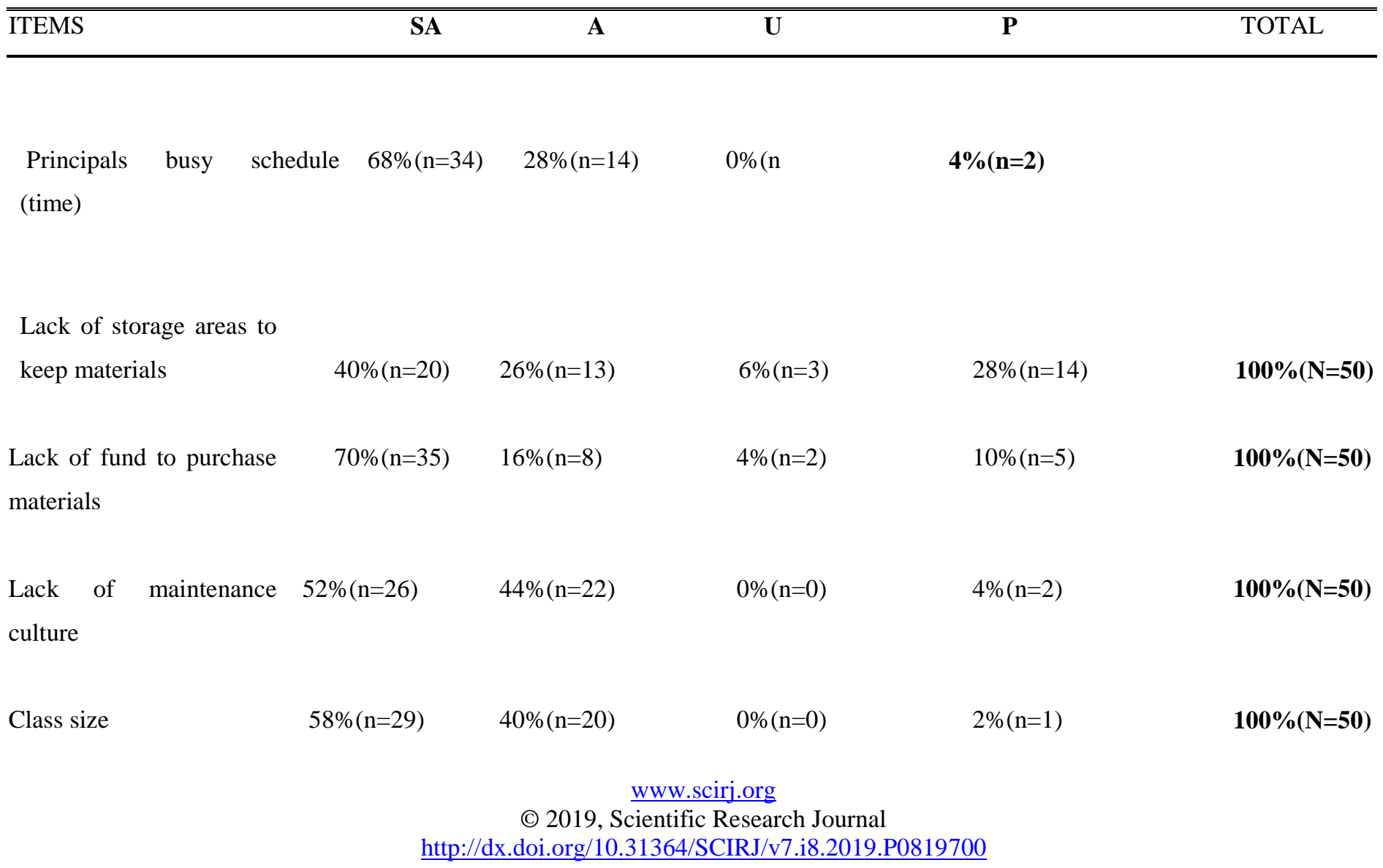


Dealing with ineffective $44 \%(\mathrm{n}=22) \quad 52 \%(\mathrm{n}=26) \quad 0 \%(\mathrm{n}=0) \quad 4 \%(\mathrm{n}=2)$

$100 \%(\mathrm{~N}=50)$

staff

Dealing with practice of $40 \%(n=20)$

$44 \%(\mathrm{n}=22)$

$6 \%(\mathrm{n}=3)$

$10 \%(\mathrm{n}=5)$

$100 \%(\mathrm{~N}=50)$

previous heads

Lack of knowledge of

$44 \%(n=22)$

$4 \%(\mathrm{n}=2)$

$14 \%(\mathrm{n}=7)$

$100 \%(\mathrm{~N}=50)$

their duties as internal

inspectors

i. $68 \%$ of the respondents strongly agree that principal's major problem is busy schedule, $28 \%$ agrees, $0 \%$ undecided, $4 \%$ of the respondents disagree.

ii. $40 \%$ of the respondents strongly agree that lack of storage areas to keep materials is a constraint faced by principals, $26 \%$ agree, $6 \%$ undecided, $28 \%$ disagrees.

iii. $70 \%$ of the respondents strongly agree that the lack of fund is a major constraints faced by the principals, $16 \%$ agree, $4 \%$ undecided, $10 \%$ disagree.

iv. $52 \%$ of the respondents strongly agree that lack of maintenance culture is a major constraints faced by the principals, $44 \%$ agrees, $0 \%$ undecided, $4 \%$ disagrees.

v. $58 \%$ of the respondents strongly agree that the size of the class is a constraints faced by principals, $40 \%$ agrees, $0 \%$ undecided, $2 \%$ disagree.

vi. $44 \%$ of the respondents strongly agree that dealing with ineffective staff is a constraints faced by the principals, $52 \%$ agree, $0 \%$ undecided, $4 \%$ disagree.

vii. $40 \%$ of the respondents strongly agree that principals are faced with dealing with practice of previous head, $44 \%$ agree, $6 \%$ undecided, $10 \%$ disagree.

viii. $38 \%$ of the respondents strongly agree that principals lack of knowledge of their duties as an internal inspector, $44 \%$ agree, $4 \%$ undecided, $14 \%$ disagree

Www.scirj.org

(C) 2019, Scientific Research Journal

http://dx.doi.org/10.31364/SCIRJ/v7.i8.2019.P0819700 
Ways to Solve the Constraints Principals Face in the Effective Utilization of Instructional Materials

\begin{tabular}{|c|c|c|c|c|c|}
\hline ITEMS & SA & $\overline{\mathbf{A}}$ & $\overline{\mathbf{U}}$ & $\overline{\mathbf{P}}$ & Total \\
\hline $\begin{array}{l}\text { Delegating } \\
\text { authority to other } \\
\text { member staff }\end{array}$ & $68 \%(n=34)$ & $32 \%(n=16)$ & $0 \%(n=0)$ & $0 \%(\mathrm{n}=0)$ & $100 \%(\mathrm{~N}=50)$ \\
\hline $\begin{array}{l}\text { Creating } \\
\text { instructional } \\
\text { materials with } \\
\text { very cheap } \\
\text { materials }\end{array}$ & $70 \%(n=35)$ & $14 \%(\mathrm{~N}=7)$ & $4 \%(n=2)$ & $12 \%(n=6)$ & $100 \%(\mathrm{~N}=50)$ \\
\hline
\end{tabular}

Frequent

classroom

visitation

Soliciting for funds

$44 \%(\mathrm{n}=16)$

$22 \%(\mathrm{n}=11)$

$2 \%(\mathrm{n}=1)$

$32 \%(\mathrm{n}=22)$

$100 \%(\mathrm{~N}=50)$

from the

community or the

parent teacher

association

Regularly check

lesson plan

Creating storage

$66 \%(\mathrm{n}=33) \quad 32 \%(\mathrm{n}=16)$

$0 \%(\mathrm{n}=0)$

$2 \%(\mathrm{n}=1)$

$100 \%(\mathrm{~N}=50)$

facilities for

keeping materials

Keeping a class size that can be managed 
i. $68 \%$ of the respondents strongly agree that delegating authority to other members is a way of solving constraints faced by the principals, $32 \%$ agree, $0 \%$ undecided, $0 \%$ disagree.

ii. $\quad 70 \%$ of the respondents strongly agree that creating instructional materials with cheap materials is a way of solving constraints faced by principals, $14 \%$ agree, $4 \%$ undecided, $12 \%$ disagree.

iii.50\% of the respondents strongly agree that frequent classroom visitation is a way of solving constraints faced by the principals, $44 \%$ agree, $0 \%$ undecided, $6 \%$ of disagree.

iv. $\quad 44 \%$ of the respondents strongly agree that soliciting for fund from community and parents is a way of solving constraints faced by the principals, $22 \%$ agree, $2 \%$ undecided, $32 \%$ disagree.

v. $72 \%$ of the respondents strongly agree that checking lesson plan regularly is a way of solving constraints faced by the principals, $28 \%$ agree, $0 \%$ undecided, $0 \%$ disagree.

vi $66 \%$ of the respondents strongly agree that creating storage facilities for materials is a way of solving constraints faced by principals, $32 \%$ agree, $0 \%$ undecided, $2 \%$ disagree.

vii. 58\% of the respondents strongly agree that keeping a class size that can be managed is a way of solving constraints faced by the principals, $42 \%$ agree, $0 \%$ undecided, $0 \%$ disagree.

viii. $80 \%$ of the respondents strongly agree that developing teachers on how to use instructional materials is a way of solving constraints faced by the principals, $16 \%$ agree, $0 \%$ undecided, $4 \%$ disagree.

\section{Discussion and Findings}

www.scirj.org

(C) 2019, Scientific Research Journal

http://dx.doi.org/10.31364/SCIRJ/v7.i8.2019.P0819700 
Having analyzed and interpreted the data collected for the research work through the administration of questionnaire, it is important to discuss the findings of the research work and evaluate them to the research questions that were initially stated from the beginning of the research.

\section{Research question 1: The role of principals in effective utilization of instructional materials}

Research question 1 sought to find out the role of principals in the effective utilization of instructional materials. With reference to table 4.3 , more respondents strongly agree that principals perform their roles in ensuring the effective utilization of instructional materials. It is clear that principals perform a lot of duties to ensure that teachers perform their jobs effectively. Shola (2009) attested in her work "principals as chief executive" where she stated that principals being instructional leaders are at a vantage position to supervise, monitor, assess, evaluate and disseminate current information on educational issues and modern teaching technique to teachers in order to stimulate best practices in curriculum delivery. She further stated that principals communicate directly and frequently with teachers about instructions and student's needs. They also check if the materials to be used are of importance to the topic to be taught. She added that schools with great principals supervision allow for teachers to do it right. This is made possible through thorough check of lesson plans. (Shola et al, 2009, p 4)

\section{Research question 2: constraints faced by principals in the effective utilization of instructional materials.}

Research question 2 sought to find out the constraints faced by principals. With reference to table 4.4 most respondents strongly agree that principals are majorly faced with constraints like busy schedule and lack of fund. It is important to note that principals perform numerous duties in schools thereby making close supervision on teachers a lot difficult. This response is in line with Mark's work (2007) "principal as the head master" where he stated that a school principal's role is a complex mix of leadership and administration. He further stated that school principals are prone to many constraints and lack adequate facilities along with some other constraints. The efficiency of a school principal in managing schools in such situation effectively exposes the capacity of a skilled school manager (Mark 2007, p 4).

\section{Research Question 3: Ways of solving constraints faced by principals in the effective utilization of instructional materials}

Research question 3 sought out to find out ways of solving constraints facing principals. With reference to table $4.580 \%$ of the respondents strongly agree that developing teachers in using instructional materials is one way of solving the principals' challenge and $72 \%$ of the respondents also strongly agree that checking teachers lesson plan is also a way of solving challenges faced by 
principals. Jarolinek (2006) in his work the "effective principal" stated that most principals are responsible for evaluating their teachers' performance. He further stated that it is the duty of principal to train teachers on how to use instructional materials and that since communication and technology is a fairly new area of importance in education especially in developing countries like Nigeria. It is a lightly technical area and to understand how it can affect teaching and learning. In developing countries today, the whole ideas and its implementation is still strange to a larger percentage of the functionalities. He strongly agreed in his article that teachers can only become knowledgeable in the use of sophisticated materials if they are properly trained. It is the duty of the principals to arrange for developmental progarmmes for their teachers. (Jarolinek 2006, p 2)

\section{Summary of the Findings}

In this chapter the researcher discusses the data of the research against a backdrop of leadership theories that are seen to be underpinning the leadership role of a principal. It emerged that strong instructional leadership is prevailing at the school which is helping the school maintain its good academic performance. It also emerged however, that like other organization, the principals faced with numerous challenges, which hamper the smooth implementations of instructional leadership.

\section{CONCLUSION AND RECOMMENDATIONS}

The role of the principal has changed from just been a facility manager to a more dynamic role ranging from checking lesson plans, visiting classrooms, ensuring teachers effectively use instruction materials to deliver their lessons, ensuring teachers use approved textbooks etc. The modern day principal ensures that the practices of teachers bring about optimal and high academic performance.

The purpose of the study was to investigate the role of principals in ensuring the effective utilization of instructional materials in selected schools. In order to achieve this aim an empirical research was conducted through questionnaires, administered to 100 teachers from selected secondary schools. The aim of the chapter is to give detailed findings emanating from the study and recommendations based on these findings.

\section{Findings}

The findings from the study were: role of principals in effective utilization of instructional materials, constraints faced by principals in performing their role, ways to solve the constraints faced by the principal in effective use of the instructional materials.

Role of principals in effective utilization of instructional materials in selected schools in Kaduna: 
1. The study revealed that principals perform their roles in ensuring effective utilization of instructional materials. It is clear that principals perform a lot of duties to ensure that teachers perform their jobs effectively. The study revealed that principals perform duties like supervision, monitoring, assessing, evaluation and disseminating current information on educational issues and modern teaching technique to teachers in order to stimulate best practices in curriculum delivery. They also check materials to be used. The study also revealed that schools with great principal supervision allow teachers to do it right which yield greater academic performance among students. The study also revealed that schools where supervision is thorough actually perform better in standardized test than schools that are not effectively supervised by principals.

2. Constraints faced by the principals in ensuring effective utilization of instructional materials in selected schools in Kaduna:

The study revealed that principals perform numerous duties in schools thereby making close supervision on teachers a lot difficult. The study also revealed that principals may be aware of their role as academic managers but problems like inadequate materials, class size, lack of skilled teachers to manipulate available sophisticated instructional materials and lack of fund stand as a barrier. The study further revealed that lack of fund prevents principals from purchasing or supplying adequate materials especially in schools with very large population.

3. Ways to solve constraints faced by principal in ensuring effective utilization of instructional materials.

The study revealed that principals can effectively supervise and ensure the proper utilization of instructional materials in schools when they delegate authority, visit classroom frequently, check lesson plans regularly and developing teaching staff. The principals' job is made easy when teachers are regularly trained and developed on how to use available materials and also ensure that materials needed are always available.

\section{Recommendation}

Principals must Supervise Teachers

The effective use of instructional materials in schools depends on the extent of staff supervision. Close monitoring, praise for any good work that has been accomplished, encouraging creativity, encouraging team work and involvement of teachers in 
problem solving and decision-making activities. Effective communication between the principals and teachers motivates teachers and create a feeling of acceptance and belonging.

2. Principals should delegate authority due to busy schedule: Principals should assign head of departments closely monitor and supervise teachers as they perform their duties in the classroom. Principals absence due to busy schedule can be replaced by the presence of head of departments and they carryout task like classroom visitation and providing support to teachers in class and ensuring teachers stay constantly on their toes. Good supervision as we know brings about improved performance.

3. Principals should regularly organize staff development programme: People are motivated by work that offers challenges to them and that contribute to self-esteem and self-actualization. People want to be developed in the work they do. Staff development programmes are very important because through this teachers are exposed to new instructional technologies like use the use of projectors, computers, and digital academic games etc. these programmes can and will motivate teachers to use available complex instructional materials. The principal should work with educators and formulate staff development programmes. This stimulates interest in educators and contributes to a feeling of ownership.

4. The government/school owners

The government or school owners cannot expect quality Education from schools that poorly resourced. It has been observed that most schools are overcrowded owing to shortage of instructional materials. In schools where there are no laboratories and libraries principals and teachers find it difficult to be effective in their delivery. The government and school owners must provide the necessary materials to schools if academic performance is to be improved.

5. In - service training for principals on supervision and staff development. Supervision of teaching and learning and staff development are important aspects of school management that enhances the quality of teaching and learning in schools. It is the duty of the government and school owners to organize seminars on supervision of teaching and learning. Staff development will improve the quality of teaching if seminars for principals are based on new strategies on supervision of teaching and learning.

6. Schools must have manageable number of learners: One major problem of effective use of instructional materials is not the availability at times but materials may be inadequate due to class size. Principals should ensure that the number of learners admitted is manageable. Factors such as number of classrooms, instructional materials and other resources should be considered when admitting learners in schools because teaching and learning will be effective when numbers are manageable. 


\section{Recommendation for Further Study}

The following area may be considered for future research into the role of principals in effective utilization of instructional materials.

i. An investigation to determine to what extent vice principals and heads of department display duties in ensuring the effective use of instructional materials.

ii. A comparative study to examine the role of educational inspectors in prompting and ensuring principals perform their roles in the effective use of instructional materials and the effective this has on schools with regard to learner achievement

\section{Conclusion}

The research has recommended a way forward in ensuring effective use of instructional materials in schools. It has also highlighted the various roles of principals in ensuring effective utilization of instructional materials in schools in Kaduna. Further research is necessary on the role of principals in the effective use of materials in schools.

\section{REFERENCES}

Agina, O.M. (2005). Effect of concept mapping on students' achievement in social studies. Unpublished Research project. University of Abuja, Abuja.

Ayo, O.L. (2008). Curriculum and instructional materials and utilization in teaching Mathematics in primary schools in Nigeria. In Journal of Curriculum and Media Technology Research. 1(1) 96-100.

Ajelabi, J.K. (2002). Instructional materials for social studies Education in Nigeria. Abakaliki: Cheney publishers.

Angela M. G. (2008). Evaluating teaching effectiveness: a practical guide. Beverly Hills: Sage publications.

Adekeye, O. A. (2012). Attitudes of teachers regarding the instructional use of computer. Master's thesis, Iowa state university, Ames, LA.

Ariyo, D. A. (2009). Quality teaching through professional development. Thousand Oaks, CA: Corwin press.

Afolabi J.K. (2009). Instructional materials and students academic achievement in schools: some policy implications. European Journal of Humanities and social sciences, 2(1), 113-126.

Ajayi G.W. (2006). Essentials of Management. New Delhi: Tata McGraw - Hill.

Anderson E.R. (2004). Instructional Methods Nairobi Education Research Publication.

Atanda T.T. (2005). Instructional Materials for Educational and Technology, Nairobi, Kenya, Kenyatta University.

Bale C.C. (2001). Administrating Secondary Schools in Nigeria for Quality output in the $21^{\text {st }}$ century: the principals' challenge. European Journal of Educational studies 2(3), 187-192.

www.scirj.org

(C) 2019, Scientific Research Journal

http://dx.doi.org/10.31364/SCIRJ/v7.i8.2019.P0819700 
Bulus K. (2008). Factors affecting students' quality of Academic performance: a case study of secondary school level. Journal of Technology and Management. 7 (11).

Bovalino K.L. (2001). Major functions of school supervision in Kenya schools. A paper presented in education forum, Kenyatta University.

Boyish J. (2003). Impact of the children television act on children's learning. Greensboro, N, Smith Richardson Foundation

Babayomi I.I. (1999). Learning from Television: Psychological and Educational Research, London: Academic press.

Bolick Y.O. (1991). Effective teaching: principles and practice, Port Harcourt Para graphic.

Bello K. (2009). The impact of Graphic Materials on Students' Academic Achievement in History. Unpublished M.Sc. (ed) Thesis University of Uyo, Uyo.

Cohen F.M. (2007). The use Audio - Visual aids in Education: extracts from UNESCO New York.

Caldwell T.J. (2002). Integrating Educational Technology into Teaching. Allan and Bacon. Boston.

Daresh T.L. (2003). Effective teaching strategies. University of Texas. Arlington

David M. (2007). "Students achievement in private Schools”, National Assessment to Educational progress”, NCES.

Dora (1997). Instructional management of a private and Government secondary school principals in Northern Pakistan: International journal of educational development, vol. 32, no. 1, pp. $120-131$.

Donald K.K. (2002). Assessing School Facilities in public secondary schools in delta state, Nigeria, African Review, vol.6 (2), No. 25, PP, 192-205.

Ejembi S.M. (2001). Major Functions of School Supervision in Kenya Schools. A paper Presented in Education forum, Kenyatta University.

Garling Y.O. (2009). The principal creative leadership for effective schools. Massachusetts: Allyn and Bacon Inc.

Ghanney H. (2008). Supervision: a guide to practice. New York: Mc Millan publishing company.

Hadfield M. (2003). Utilization of equipment and facilities for teaching and learning in technical colleges in Nigeria. Journal of Education Research and development. 3 (1) 100-108.

Heuser M. (2000). "School principals and school performance,” The Urban Institute Working paper no 38, Washington, DC

Jekayinfa O.S. (2010). How Instructions can be adapted to individuals' differences. Public Education, New York. Basic books Inc.

Joshua D. (2007). Cognitive principles of multimedia learning: The role of modality and contiguity. Journal of Educational and Policy Analysis. American Journal of Education, 3158.

Kajang A.H. (2000). The selection and use of instructional materials: implications for teachers' effectiveness. Journal on Education. Media and technical 3. (1) 66-68

Kamaldeen H.A.(2013). Teacher leadership: principles and practices. A paper for the national college for school leadership, Nottingham, England.

Keri J.J. (2009). Effective instructional leadership Requires Assessment Leadership. Phi Delta Kappan 90. (4) D.

Leithwood A.L.(2005). Designing powerful professional development for teachers and principals. National staff development council. Oxford. Accessed online at www.nsdc.org (25 February 2012).

Lovell F.C. (2004). The Training and development of Principals in the Management of educators. Unpublished Doctoral Thesis. Johannesburg. Rand Afrikaans University. 
Montague H.H (2003). Educational Administration, Ibadan: Oluyole printing press.

Morunfola O. (2009). Instructional leadership: how principals make difference. Association for Supervision and Curriculum Development. Alexandria, Virginia.

Momoh A. (2008). School Effectiveness and Teacher Effectiveness in Physical Education. Paper presented at the $85^{\text {th }}$ Annual meeting of the American Educational Research Association. Chicago, USA.

Nsa, Ikot and

WwW.scirj.org

(C) 2019, Scientific Research Journal 